\title{
Architecture in the public space - streets and squares under the conditions of urban globalization
}

\author{
Dariusz Gaweł \\ https://orcid.org/0000-0001-5759-1962 \\ d.gawel@pollub.pl \\ Department of Contemporary Architecture, Lublin University of Technology
}

\begin{abstract}
This article is the result of the research carried out by the author in creating new public spaces and shaping contemporary urban-forming trends in the conditions of globalization. In his research (through literature criticism and in situ field research) the author analyzes selected contemporary architectural realizations in Poland over the last decades, comparing them with similar works around the world, assessing their impact on shaping the cities' build environment. The comparison is made through the analysis of such factors as: the construction of the form, elements of architecture and construction affecting the location, visibility, perception and created relations between the building and the surroundings.
\end{abstract}

Keywords: architecture, city, public space, streets, squares, globalisation

\section{Introduction}

The main aim of this article is an attempt to define the factors shaping architectural objects within urban space, in the conditions of ubiquitous globalization. Awareness of creating the urban development of cities and human settlements from the earliest times predisposed architects to the creators' elite. The sense of creating space, by giving it the characteristics of a place, was to justify individual, sometimes sublime forms. The buildings and constructions that have been created for centuries had not only to fulfill utilitarian and structural functions, but also, by influencing the imagination, they stimulated aesthetic impressions. A specific dialogue between the creator and the recipient of the work - the user, which has been taking place in front of our very eyes for several thousand years, aimed at forcing to give architecture a new dimension, a philosophical dimension. The philosophical "techne" becomes part of the creator's communication with the addressee of the work and influences the interactions between human cultures. It was believed that when people talk to each other, they use their knowledge more often. By seeking a balance between the "techne" and the "arche", the fleeting metaphysical strength of the created object was to give it additional value. This value should come from the sensitivity of the creator, exhibited in the culture of the created form of expression and the sense of the specificity of the conditions of incorporation into the city's urban environment. [Shepard J., Gregory J.; Jeffrey St. John; Theodore G.2006]

\section{Contemporary globalised urban environment - benefits or social disapproval}

The progressive urbanization of cities is not limited to the creation of monstrous tower blocks estates. It was quickly understood that the organization of urban space must have its reflection in the growing needs of residents. This was noticed already in 1933 in the postulates of the Athenian Charter, which for many years set 
the direction for change. According to research, we spend more than half our lives outside the home. In the workplace and on the way to it, in restaurants, cinemas, museums, during walks in the park, going into public institutions and the church, or on the way home. All the places visited are within public space. [Czarzasty; Szymańska 2016 ]

Nowadays, it is on the Asian continent that the largest urbanization processes take place. Rapidly emerging cities in Asia (in areas of the fastest industrial and economic development), had to quickly respond to the requirements that were set for them in order to meet the residential needs of society. Shaped living environment in Asian countries has undergone a kind of evolution from nameless spaces in the city's dormitories to organized places with individual characteristics and influencing the standard of living. [Gawel 2017] According to many designers and scientists, the negative effects of globalization in the creation of cities will consist in the emergence of increasingly similar (nameless) public spaces, and thus architectural objects themselves. This happens when the dialogue between the designer and the space user is no longer possible. Rapid and uncontrolled process of economic development of cities has deprived residents of the feeling of social satisfaction, acceptance and joy of staying within crowded, busy squares and streets. People began to flee to parks and squares looking for a sense of security and rest. [Gawel 2018] The search for breathing room and relaxation in public spaces is very often done by resting among familiar forms, gentle light and related calm color patterns. The feeling of contentment (according to psychologists) [Bańka 1997] with being in a given space can be obtained by:

the use of liquid and round shapes of objects,

a combination of contrasting forms, large and small, within the scale readable to people,

- introducing moving and dynamic elements into the urban interior,

application of repetitive rhythms,

- designing objects expressing common and understandable creative ideas (eg expressionism, symbolism or functionalism).

These general remarks can be seen in many design solutions. However, the clarity and simultaneously allowing individual expression of urban space is associated with the use of specific styles and patterns. The general international style created before World War I was described as innovative. In turn, immediately after the war, as a result of chaos appearing in the life of city dwellers, new trends in urban planning (Le Corbusier or Garnier) and architecture began to be sought. The new international style began to be prosocial, creating more and more repetitive patterns. In the following years, the ideas of modernism quickly penetrated into social life, hence it did not encounter social resistance and disapproval, undergoing further transformations. [9]

\section{The street and the square as the object insertion site}

In the course of the conducted research, it was attempted to identify characteristic places in the urban public space for the location of architectural objects. Various functions of objects have been noted, being at the same time a contribution to their location within districts or cities themselves. (Tab.1) However, the basic source of guidelines deciding on the place of incorporation was data resulting from the current provisions of spatial development plans. In its content, it specified the parameters and building lines, taking into account social expectations. The evolution in planning consisted in abandoning norms, abandoning the respect of official urban documents, taking into account the new spatial policy, in line with the expectations of the inhabitants. [Chyłowa-Heczko E. 1999] In the course of the conducted research, three basic locations were distinguished, within the built environment of cities: historical (cultural) and landscape surroundings, urban squares, streets (including corners).

\section{Historical (cultural) and landscape surroundings}

Creating historical urban layouts very often began with squares, streets or parcel divisions. In time, the area grew in new buildings, generating a residential environment that is necessary for living. The origins of most 
historical urban systems can be found in medieval times. The traditional historical layouts of streets, quarters, and existing plots that have survived to the present are the backbone of the future urban structure. The unique value of a place shaped for many centuries includes its undeniable cultural value. Nowadays, the values and the social acceptance of a city or district are determined by the ways and conditions of preserving the historical environment, including its authenticity. The awareness of renovating buildings requires carrying out the necessary research, studies and preliminary projects. Supplementing the structure through contemporary architecture also requires a specific compromise between cultural values and the present. The aim of such actions is to preserve the living organism serving the modern needs of life with the maximum preservation of the cultural heritage contained in the urban complexes. [Małachowicz 2007].

\section{The urban square}

In their realizations, the creators more often chose locations related to the possibility of displaying the work, which is why they are more often squares. In immemorial times, with the appearance of sacral and burial architecture, humanity sought to concentrate the most important architectural objects within the squares. In the Mediterranean culture, they had their beginnings as agora and forums, with time transformed into urban markets. They have always been places gathering the largest number of inhabitants and also vital elements of the city structure. As human settlements increased due to the change in the way of life of their inhabitants, they began to multiply reaching the character of urban nodal points. The architecture created in these places has a chance for a better presentation, access to light or complementation through the urban detail. At the same time, the requirements related to its housing enforce many conditions. It is about the organization of rest areas and the creation of a coherent spatial composition with a drawing of the floor.

Table 1. Analysis of world's examples contemporary architecture in urban space - the author's elaboration (urban characteristics)

\begin{tabular}{|c|c|c|c|c|c|}
\hline No. & Object & City & Location & Surroundings & Environment \\
\hline & 1 & 2 & 3 & 4 & 5 \\
\hline \multicolumn{6}{|c|}{ Urban, historic and landscape environment } \\
\hline 1 & $\begin{array}{c}\text { Shakespeare } \\
\text { Theater }\end{array}$ & Gdansk & square & $\begin{array}{c}\text { tenements \& } \\
\text { highway }\end{array}$ & historical district \\
\hline 2 & $\begin{array}{l}\text { The Louvre } \\
\text { Pyramid }\end{array}$ & Paris & square & $\begin{array}{c}\text { fountains } \& \\
\text { Louvre buildings }\end{array}$ & monuments \\
\hline 3 & Philharmonic & Szczecin & street & $\begin{array}{c}\text { tenements \& } \\
\text { greenery }\end{array}$ & historical district \\
\hline \multicolumn{6}{|c|}{ Urban environment - square } \\
\hline 4 & Dongadeum & Seoul & square & $\begin{array}{l}\text { commercial } \\
\text { centers }\end{array}$ & $\begin{array}{l}\text { commercial } \\
\text { district }\end{array}$ \\
\hline 5 & $\begin{array}{l}\text { Heydar Alijew } \\
\text { Center }\end{array}$ & Baku & square & greenery & residential district \\
\hline \multicolumn{6}{|c|}{ Urban environment - street } \\
\hline 6 & Dancing house & Prague & corner street & tenements & residential district \\
\hline 7 & Bonjour Tristesse & Berlin & corner street & tenements & residential district \\
\hline
\end{tabular}

\section{The street}

Analyzing the presented objects, it can be stated that the designers do not treat the street location as the right place for the construction of an architectural object (supplementing the buildings). Disapproval probably results from the conditions of neighboring buildings or limitations resulting from the lack of space for creating 
a building with the appropriate function and scale. The street has never been appreciated by designers as a place to build. With the rapid development of transport and urban infrastructure, the street has become an insignificant place. The sidewalk itself can only mean something in connection with the building. [Jacobs 2014] Streets and sidewalks seem to be the main public spaces of cities that should serve other purposes than just vehicular traffic. A slightly different situation appears in the case of the location of objects on street corners. This location with the created "pseudo" square, under certain conditions, may allow for the display and presentation of the building.

\section{The object form and the contemporary global architecture trends}

The creation of modern architecture in a built environment requires its creators to sign in to the current trends and styles of urban development. The lack of a strictly defined dominant direction in the field of creating space and objects connected with it resulted in liberalism starting to be perceived as the key to the encroaching economy. That is why "sustainable development" as a direction began to be perceived in terms of freedom, supported by acceptance and social dialogue (with the user) with integration into greenery in the surrounding landscape. At a time when the whole world creates ever higher objects outdoing one another with more and more new technologies allowing for juggling between "concrete, steel and glass", Europe focuses all its creative attention around revitalization and modernization of what has already been created. Giving the artist individual characteristics is needed and even advisable to emphasize the character of the transformed public space. The issue is appearing when architecture begins to fight the very space. It manifests itself in taking over the urban space, determining it, while giving certain features. Deconstructivism and blobitecture [10] have become the directions that best fit into the kind of emptiness created after postmodernism. These directions were fresh and bold in their message.

The modern technical possibilities of using computers have allowed designers to create (the highest possibility of creating) forms of organic and oval objects, often with rounded and soft shapes. This type of object looks more like a sculpture, a work of an artist which requires proper exposure and framing. When analyzing these modern objects in terms of function, it should be noted that multifunctional buildings are being built all the time, with sometimes monumental open communal spaces. Transparent glazing of entire planes allow space to penetrate, without using the wall as a partition. Another important element of the building is the window, or its elimination. The introduction of reduced windows in the form of their elimination or reduction of the separation of storeys and rhythms allows for the determination of new divisions of planes. Walls that are there but they aren't there, windows that are there but aren't, and as a consequence, there is only a roof large, rounded, wavy in many places and at the same time consistently the same. These modern architectural trends are often referred to as controlled chaos. It creates a new way of perceiving a building in urban space.

\section{The architectural object in an urban environment - an analysis of selected}

The ever present rivalry of many cities around the world in the field of erecting new buildings, whether through organized competitions or other forms of creator competition, led to the creation of projects combining many challenges. Modern objects not only exert aesthetic impressions, but more and more often combine new functionalities such as: energy efficiency, ecology or mobility of shaping the structure. The buildings analyzed here are positive examples of modern architecture, with their distinguishing features. (Tab.2.)

\section{The location of buildings in a historic surrounding}

Completely different problems are experienced by designers of new facilities in the historical environment, in the immediate vicinity of historic buildings. One can not speak here about planning or landscape dominants, the creators concentrate more on the simplicity of the message, logical, clear forms, or even poetics. Some theorists define a space for design in such conditions as a theatrical one, a spectacle that takes place before 
our eyes between modernity and cultural features. [Hastrup 2004] This was not the case with the Shakespearean Theater in Gdansk. The building has been a source of controversy since its inception. It was believed that it boldly interferes with the historical urban panorama. [Stiasny 2014] Through the use of dark façade solutions, as well as simple geometrical shapes, it was bravely announcing a breakthrough in design in the vicinity of monuments. This approach must have been objectionable. In time, it was accepted by the residents, not as a form of a "massive casket" (with a closed roof serving as a form of a lid), but as a building with sacral accents. [Kuzlanik 2014] This was perceived as a local feature, because in the Western tradition, artists created a gap between religion and art. [Newling 2007] Sacral motifs can also be seen in another project - the entrance to the Louvre, in the shape of a glass pyramid. From a spatial point of view, the design has been exceptionally refined, by separating into different directions underground in the interior and using water as a mobile element (which is also an external barrier that prevents access). After analyzing the scheme of location guidelines, from the western elevation of the Louvre to the Place d'Etoile in Paris, one can find links between the sharp edges of the prism of the glass pyramid and the strong form of the urban axis. [Żurawski 1962] Yet another approach is represented in the case of the Szczecin Philharmonic. The building is seen by some as a towering iceberg, by others as a connected space of the tops of tenement houses. The medium of expression used by the creators of the object was light and monochromatic architectural message. The building is admired for combining a rather harsh modest external form and sparing but soft shapes inside, characterized by exceptional acoustics, which is its additional asset.

a)

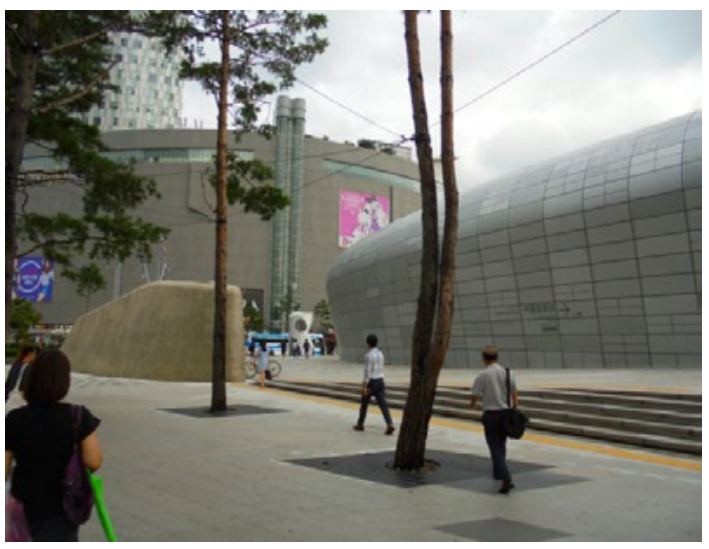

b)
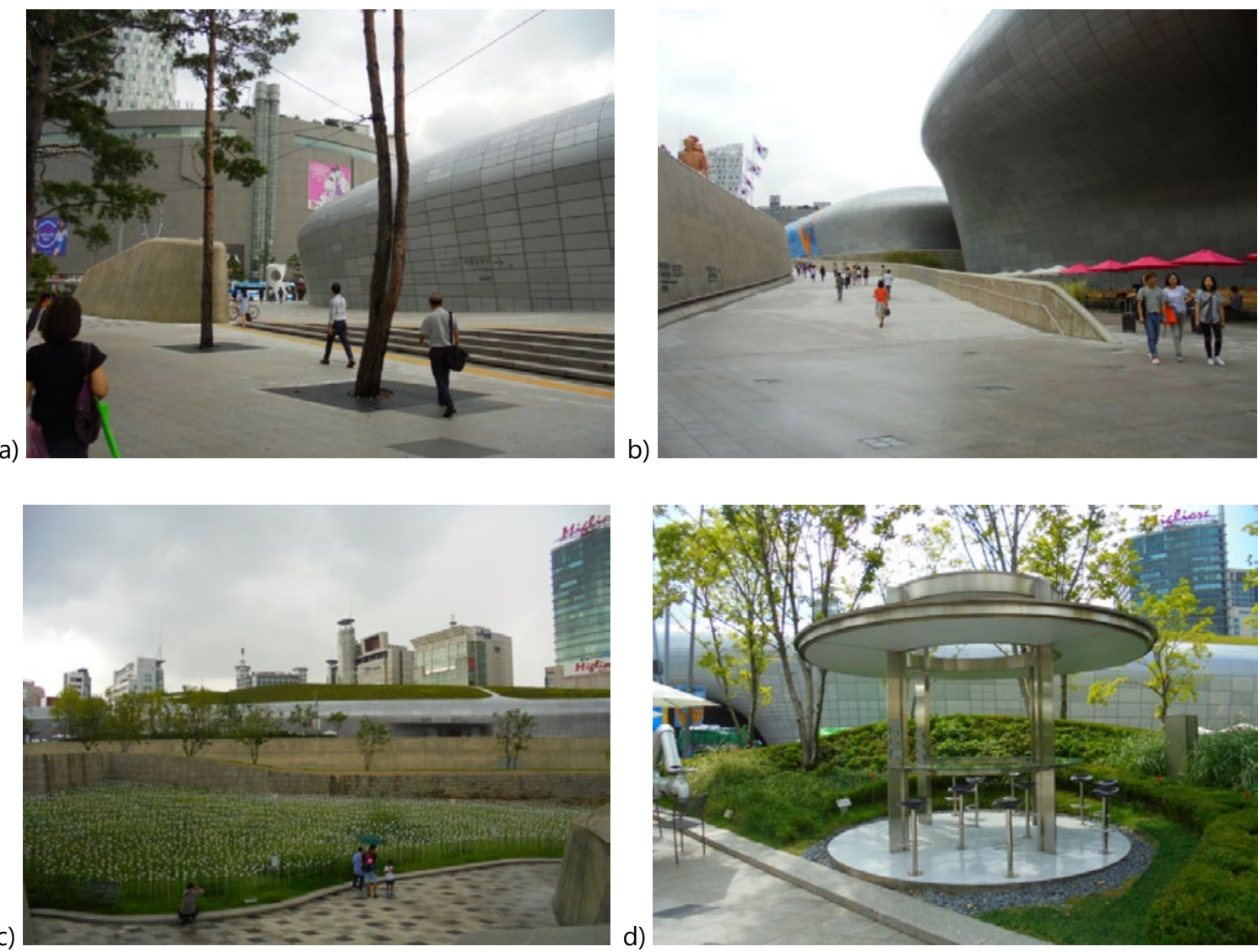

d)

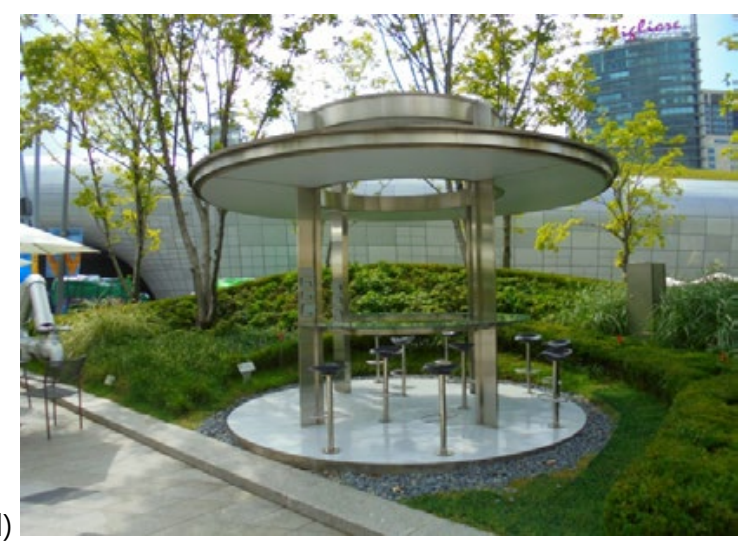

Fig. 1. Seoul - Dongadeum, a, b-general views from the square, c. greenery at the back, d. site detail. Fot. author 2017 


\section{The location of buildings within squares}

The following two buildings, although they are products of the same design studio, function in completely different realities of the city square and the function they serve. The Dongadeum building for the residents of Seoul is a hub node where 3 metro lines cross. The space availability causes that despite the complex shape, it has become part of the urban landscape. Modernity of the metallic outer housing solution, combined with the merger of the building plan, makes users view and treat this place as a meeting point. The location of the square allowed for the creation of an interesting green square in the city center as a place of rest for the residents.

The Center of Haydar Aliyev in Baku, due to its proportions, its round shape and its fluid form became, next to the Fire Towers, a symbol of the capital and even a symbol of Azerbaijan. However, the location - detached from the center - resulted in the object's even further perception as a monumental form. The oblong shapes of both objects and the free form of the projection translated into the shaping of the mass and the interiors. Created as spatial dominants in the city, they perform extremely different functions. Despite the economic successes in Azerbaijan, the country is not fully open to the West, which can be manifested in the way in which space is treated.

Table 2. Analysis of world's examples contemporary architecture in urban space - the author's elaboration (architecture characteristics)

\begin{tabular}{|c|c|c|c|c|c|c|}
\hline No. & Object & City & Style & Function & Form & Fasades \\
\hline & 1 & 2 & 3 & 4 & 5 & 6 \\
\hline \multicolumn{7}{|c|}{ I. Urban, historic and landscape environment } \\
\hline 1 & $\begin{array}{c}\text { Shakespeare } \\
\text { Theater }\end{array}$ & Gdansk & $\begin{array}{l}\text { modern } \\
\text { building }\end{array}$ & theater & monumental & black brick \\
\hline 2 & $\begin{array}{l}\text { The Louvre } \\
\text { Pyramid }\end{array}$ & Paris & $\begin{array}{c}\text { post- } \\
\text { modernism }\end{array}$ & $\begin{array}{l}\text { gate to } \\
\text { museum }\end{array}$ & $\begin{array}{l}\text { monumental } \\
\text { regular form }\end{array}$ & glass \\
\hline 3 & Philharmonic & Szczecin & $\begin{array}{c}\text { modern \& } \\
\text { smart building }\end{array}$ & philpharmonic & $\begin{array}{l}\text { monumental } \\
\text { regular form }\end{array}$ & $\begin{array}{l}\text { semi trans- } \\
\text { parent panel } \\
\text { illuminated }\end{array}$ \\
\hline \multicolumn{7}{|c|}{ II. Urban environment - square } \\
\hline 4 & Dongadeum & Seoul & $\begin{array}{l}\text { deconstruc- } \\
\text { tionism }\end{array}$ & $\begin{array}{l}\text { exhibition } \\
\text { center }\end{array}$ & $\begin{array}{c}\text { free form } \\
\text { irregular \& } \\
\text { round shape }\end{array}$ & $\begin{array}{l}\text { aluminium } \\
\text { panel }\end{array}$ \\
\hline 5 & $\begin{array}{c}\text { Center of } \\
\text { Heydar Alijew }\end{array}$ & Baku & $\begin{array}{l}\text { deconstruc- } \\
\text { tionism }\end{array}$ & $\begin{array}{l}\text { exhibition } \\
\& \text { museum } \\
\text { center }\end{array}$ & $\begin{array}{l}\text { free \& fluid } \\
\text { form }\end{array}$ & $\begin{array}{l}\text { glass } \\
\text { aluminium } \\
\text { panel }\end{array}$ \\
\hline \multicolumn{7}{|c|}{ III. Urban environment - street } \\
\hline 6 & $\begin{array}{l}\text { Dancing } \\
\text { house }\end{array}$ & Prague & $\begin{array}{l}\text { deconstruc- } \\
\text { tionism }\end{array}$ & office & $\begin{array}{l}\text { multielement } \\
\text { free form }\end{array}$ & glass \\
\hline 7 & $\begin{array}{l}\text { Bonjour } \\
\text { Tristesse }\end{array}$ & Berlin & modernism & housing & $\begin{array}{l}\text { monument al } \\
\text { regular form }\end{array}$ & $\begin{array}{c}\text { wall plaster } \\
\text { window rhytm }\end{array}$ \\
\hline
\end{tabular}

\section{Street location}

In the case of street (corner) locations, both the Dancing House in Prague and the Bonjour Tristesse in Berlin are located in residential districts. Their creators' approach to the implementation was extremely different. The Berlin residential building is an orderly form with regular levels and risers, identical windows, and a slightly undulating elevation. The gently emphasized corner of the street, by applying the waving peak line of the facade, closes the whole. [Gregotti V .; Frampton K .; Wang W. 1989] As a consequence, this piece was treated as a dignified building, in which the designer achieved his goal thanks to the simplicity of the message. The 
Prague building is completely different, it has a dynamic multi-element form of seemingly conflicting shapes. It is a contradiction to order, rhythm, staggering with its uneven shape, permeating structures and a glass façade. The buildings connect with the neighboring buildings creating a quarter closing. Both projects, despite the use of extremely different means of artistic expression, have become works of architecture, inspiring admiration in ordinary passers-by and visitors to these places. Noteworthy are the corner locations, as a special highlight of the street location.

\section{Conclusions}

Conclusions from the analysis of examples of architecture and urban-forming trends that appear in many cities can be summarized by formulating the following comments:

Contemporary cities and the places and public spaces shaped in them require an individual approach from their creators. By defining a place, the designer does not only take on himself, but also accepts the evaluation from other users. The factors that influence the success and acceptance of the object by the recipients are: scale, form, location, exhibition or the surrounding of the place (its character, described as individual features within the built environment). [8]

Architecture created in public places through its individual values (of the created object with the appropriate aesthetic culture) becomes a symbol of sorts. Bestowing the value of a public space to an area is usually done through architectural objects and other elements of urban composition, allowing a sense of harmony, security and integration with others. The role of objects of urban detail, greenery or the combination of walls and the floor of an urban interior should also be mentioned here.

As is apparent from the analysis carried out, the location within city squares is the most frequently chosen one fora more favourable reception of architecture. This can probably be explained by the larger and more impressive display of the object within an open space. However, it seems equally important to supplement the building as an architecture that fills urban structures.

Along with the creation of more and more impressive examples of architecture, the informal separation of space through the creation of barriers and fences is more frequently noted. This phenomenon can be dangerous enough that it sometimes leads to social divisions.

Some of the objects created take on the character of multifunctional buildings. This is most often due to the need for economic utilisation of their cubage in terms of ensuring appropriate and cost-efficient use. The multifunctionality of a building imposes on designers the necessity of combining many different related functions, allowing the creation of complexes corresponding to contemporary social needs.

The avant-garde architecture created in urban spaces is also often verified with time. The object, known and accepted by the residents, is no longer offending in its aesthetics, after a few, and more often after several dozen years (e.g. Galeria Solpol in Wroclaw). A project that is not understood but recognizable can become "art" through architectural, urban and compositional features (e.g. the Katowice Spodek or the Szczecin Philharmonic). A structure created with strong architectural culture (with a suitably built form and aesthetic values), but not accepted, can defend itself in the context of the passing time.

Globalization in the conditions of functioning of cities as a negative phenomenon should be perceived in terms of creating repetitive objects and places that generate indifferent relations in urban structures. This is not only a phenomenon noted in Polish conditions, but a trend with an international dimension. Repeatability, economics of production, unification, unification of patterns or the pace of life can result in often experiencing a "déjà vu" of sorts in the perception of public space for leisure, housing and work. 


\section{References}

[1] Bańka A., Architektura psychologicznej przestrzeni życia. Gemini S.C., Poznań 1997, pp. 115-116.

[2] Chyłowa-Heczko E., Francuskie doświadczenia w zakresie planowania na przykładzie Lyonu w odniesieniu do sytuacji planistycznej w Polsce [w:] Przestrzeń Europy, Stowarzyszenie Urbanistów Polskich o. Warszawski, Warszawa 1999.

[3] Czarzasty P., Szymańska B., Architektura przestrzeni publicznych, Akademia Sztuk Pięknych w Gdańsku, Gdańsk 2016, p. 9.

[4] Gawel D., Synergia w ekonomii, jako czynnik miastotwórczy, [w:] Budownictwo i Architektura, vol. 16 (1), Politechnika Lubelska, Lublin 2017, pp. 213-221.

[5] Gawel D., Strategiczne węzły miejskie w wielkich miastach Azji Południowo-Wschodniej, (w:) Budownictwo i Architektura, vol. 17 (2), Politechnika Lubelska, Lublin 2018, pp. 171-182.

[6] Gregotti V., Frampton K., Wang W., Alvaro Siza 1954-1988, Architecture and Urbanism Publishing Co. Ltd. Tokyo 1989.

[7] Hastrup K., The imaginative texture of social spaces (w:) Space and culture, International Journal of social spaces., vol. 7 (2), SAGE Publications, 2004, pp. 223-236.

[8] Internet source, availability on October 26, 2018, http://www.miasto2077.pl/kilka-porad-jak-ksztaltowac-miejska-przestrzen.

[9] Internet source, availability on October 26, 2018, http://www.panol.lublin.pl/wydawnictwa/TArch2/Machaczka.pdf.

[10] Internet source, availability on October 26, 2018, http://www.propertydesign.pl/architektura/104/kierunki_architektoniczne_w_ europie_a_w_polsce,3278_1.htm.

[11] Jacobs J., Śmierć i życie wielkich miast amerykańskich, Fundacja Centrum Architektury, Warszawa 2014.

[12] Kuzlanik R., Teatr Szekspirowski w Gdańsku - Otwierany dach, (w:) Architektura, Vol. 11, Murator S.A., Warszawa 2014, pp. 46-47.

[13] Małachowicz E., Konserwacja i rewaloryzacja architektury w środowisku kulturowym, Oficyna Wydawnicza Politechniki Wrocławskiej, Wrocław 2007, pp. 399-400.

[14] Newling J., An Essential Disorientation, An investigation into sacredness and its relation to contenporary art. SARP Stowarzyszenie Architektów Polskich o. Kielce, Kielce 2007, pp. 54-55.

[15] Shepard J., Gregory J., Jeffrey St. John, Theodore G., Communication as Techne. Communication as... Perspectives on Theory, 2006, pp. 90-91.

[16] Stiasny G., Filozoficzno-logiczny traktat, (w:) Architektura, Vol. 11, Murator S.A., Warszawa 2014, p. 52.

[17] Żurawski J., O budowie formy architektonicznej. Arkady. Poznań 1962, pp. 117-118.

\section{Architektura w przestrzeni publicznej - ulice i place w warunkach globalizacji miast}

Streszczenie: Artykuł jest wynikiem kontynuacji badań prowadzonych przez autora w zakresie tworzenia nowych przestrzeni publicznych i kształtowania współczesnych trendów miastotwórczych w warunkach globalizacji. W swoich badaniach (poprzez krytykę literatury i badania terenowe „in situ”) autor dokonuje analizy wybranych współczesnych realizacji architektonicznych w Polsce na przestrzeni ostatnich kilkudziesięciu lat, porównując je z dziełami światowymi, oceniając ich wpływ na kształtowanie środowiska zbudowanego miast. Porównanie dokonywane jest poprzez analizę takich czynników jak: budowa formy, elementy architektury i konstrukcji wpływające na lokalizację, wyeksponowanie, postrzeganie oraz wytworzone relacje pomiędzy budynkiem a otoczeniem.

Słowa kluczowe: architektura, miasto, przestrzeń publiczna, ulice, place, globalizacja 